Instructions for authors, subscriptions and further details:

http://ijelm.hipatiapress.com

\title{
Transforming education through teacher leadership
}

Rocío García Carrión ${ }^{1}$

1) University of Deusto. Spain

Date of publication: July $16^{\text {th }}, 2015$

Edition period: July 2015-January 2016

To cite this article: García Carrión, R. (2015). Transforming education through teacher leadership. [Review of the book] International Journal of Educational Leadership and Management, 3(2), 219-221. doi:

10.17583/ijelm.2015.1588

To link this article: http://dx.doi.org/10.17583/ijelm.2015.1588

\section{PLEASE SCROLL DOWN FOR ARTICLE}

The terms and conditions of use are related to the Open Journal System and

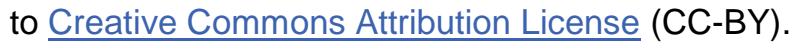




\section{Review}

Frost, D. (2014). Transforming education through teacher leadership. Cambridge: Leadership for Learning.

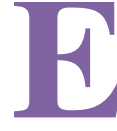

very single teacher can lead and act strategically. Even those who had no plans to change the world become agents of change, collaborate enthusiastically with others and engage in critical dialogues that empower them to make an immense difference in their schools and communities. This idea illustrates the non-positional teacher leadership that is at the heart of the book Transforming education through teacher leadership edited by Dr David Frost, University of Cambridge. This is a book that cultivates hope, speaks a language of possibility, and reminds us of the ultimate meaning for what we are teachers: transform education and improve people's lives.

Theory, research and practice are woven through narratives, which are essentially 'moral tales' (p.3) and encourage the reader to pursue the nonpositional teacher leadership as a real possibility to transform education. Assuming the belief that 'all teachers and education practitioners have some leadership capacity' (p.2) the HertsCam and the wider International Teacher Leadership Network have mobilised teachers as agents of change 
worldwide. Such transformative work is brilliantly presented in this book through multiple voices of 26 teachers from 6 different countries. All together show what Freire called 'unity in diversity' (Freire, 2006: 137); they are very diverse, from the UK to the Balkans, some of them work in very challenging contexts, but all of them mobilise and share a moral purpose. Through the stories of Marie, Claudette, or Merita, we understand how moral purpose builds and travels to enable real teachers to make an enormous difference in the lives of their students.

Those stories are part of the first section of the book that includes eight chapters; each of them unveils a powerful and extraordinary story within which teachers develop a specific project -from food technology to geography or dance- using the 'teacher-led development work' methodology (TLDW and presented in detail later in the book, Ch. 13). These projects address very different professional concerns, but all of them speak a common language: the language of teacher leadership. This is a language of possibility that makes things happen within the HeartsCam Network and the linked International Teacher Leadership (ITL) initiative and energizes teachers to lead successful innovations, build school effectiveness and enable others to lead.

Teachers work remarkably hard and commit themselves to develop their projects with a strong scholarly dimension. The second section of the books presents teachers' contributions resulting from their involvement in the MEd in Leading Teaching and Learning which is a master's degree currently awarded by the University of Cambridge. As a result of this 'practicefocused scholarship' (p.32) the four stories provide evidence of improving the quality of teaching and learning. They demonstrate higher order thinking and reflection when using evidence-based strategies - like neuroeducation -, because teachers not only 'implement' those strategies but question that knowledge and enable others to use and engage with research.

How do these stories become real? What we can do to support teacher leadership? 'Accounts of the facilitation of programmes to support teacher leadership' -the third section - provides us with some key strategies. Facilitators of these programmes in different parts of the world tell us about the transformative dimension and provide specific details of the HertsCam TLDW programme, the teacher leadership programme in Turkey, and the participation of ethnic minority families in Bosnia. This presents an inspirational combination of supportive frameworks and structures linked to 
concrete actions to improve practice. Val Hill presents one of the most profound and meaningful ideas that is truly inspiring:

It remains our commitment to retain a focus on the moral purpose of improving the life chances of the students in schools by supporting teachers who wish to develop their own and their colleagues' practice, while at the same time ensuring that the critical scholarship entailed in this process can be recognised as academically valid.

Creating a global network involves celebrating the possible. Towards the end of the book, we discover teachers' networks events on an international scale. Within these events teachers' professionality transcends national boundaries. Far from utopianism, HertsCam and ITL are generating real utopias (Wright, 2008), envisioning transformative educational practices that can inform our practice and lead to social change.

\section{References}

Freire, P. (2006) Pedagogy of Hope. New York: Continuum.

Frost, D. (ed.) (2014) Transforming education through teacher leadership.

Cambridge: Leadership for Learning.

Wright, E.O. (2008) Envisioning Real Utopias. London: Verso.

Rocío García Carrión

Universidad de Deusto 
222 R. García Carrión - Transforming Education through Teacher Leadership 